WOMEN AND

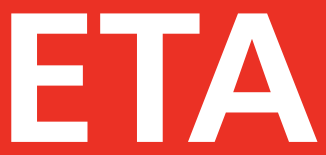

The gender politics

of radical Basque nationa 1 ism 


\section{Women and ETA}

\section{MANCHESTER 1824}

Manchester University Press 
Carrie Hamilton - 9781847791443 Downloaded from manchesterhive.com at $04 / 26 / 2023$ ๑8:53: ๑9AM via free access 


\section{Women and ETA \\ The gender politics of radical Basque nationalism}

Carrie Hamilton

Manchester University Press

Manchester 
Copyright (@) Carrie Hamilton 2007

The right of Carrie Hamilton to be identified as the author of this work has been asserted by her in accordance with the Copyright, Designs and Patents Act 1988.

Published by Manchester University Press

Altrincham Street, Manchester M1 7JA, UK

www.manchesteruniversitypress.co.uk

British Library Cataloguing-in-Publication Data is available

Library of Congress Cataloging-in-Publication Data is available

ISBN 9780719089060 paperback

First published by Manchester University Press in hardback 2007

This paperback edition first published 2013

The publisher has no responsibility for the persistence or accuracy of URLs for any external or third-party internet websites referred to in this book, and does not guarantee that any content on such websites is, or will remain, accurate or appropriate. 